\title{
RICHNESS AND PALAEO-ZOOGEOGRAPHICAL SIGNIFICANCE OF THE BENTHIC OSTRACODA (CRUSTACEA) FROM THE OCEANIC ISLAND OF TRINDADE AND ROCAS ATOLL, BRAZIL
}

\author{
JOÃO CARLOS COIMBRA \\ Instituto de Geociências, UFRGS, Av. Bento Gonçalves, 9500, Cx. 15001, 91501-970, Porto Alegre, RS, Brasil. \\ joao.coimbra@ufrgs.br
}

ANA LUISA CARREÑO

Instituto de Geologia, UNAM, Circuito Exterior, C.U. Delegación de Coyoacán 04510, D.F., México.anacar@geologia.unam.mx

\begin{abstract}
Twenty-one ostracode species from Trindade Island and 23 species from Rocas Atoll are herein recorded. The collective fauna shows low richness and low abundance compared with other oceanic islands. Nevertheless, the presence of tropical pandemic species such as Kotarocythere inconspicua (Brady) and Triebelina sertata Triebel, of the almost exclusively Pacific genus Australimoosella, the Atlanto-Caribbean taxa such as Glyptobairdia coronata (Brady) and Caudites obliquecostatus Bold, together with species typical of the Brazilian shelf, reveals a mixed fauna likely influenced by dispersal of shallow-water taxa between seamounts during Quaternary sea-level lowstands. In contrast to other oceanic islands, endemic ostracode taxa are apparently absent in these two islands. Tenedocythere trindadensis sp. nov., a species also recorded on the Brazilian equatorial shelf, is described and illustrated.
\end{abstract}

Key words: oceanic island, ostracodes, Rocas Atoll, Trindade Island, zoogeography, paleozoogeography.

RESUMO - Foram registradas 21 espécies de ostracodes para a Ilha da Trindade e 23 para o Atol das Rocas. Ambas ostracofaunas mostram baixa riqueza e abundância de espécies quando comparadas com outras ilhas oceânicas. Contudo, a presença de espécies tropicais pandêmicas, como Kotarocythere inconspicua (Brady) e Triebelina sertata Triebel, do gênero Australimoosella que é quase exclusivo do Pacífico, e de táxons atlântico-caribenhos como Glyptobairdia coronata (Brady) e Caudites obliquecostatus Bold, juntamente com espécies típicas da plataforma brasileira, revela uma fauna mista provavelmente influenciada pela dispersão de táxons de águas rasas entre montes submarinos durante períodos de mar baixo ao longo do Quaternário. Contrastando com outras ilhas oceânicas, estas duas ilhas parecem não apresentar espécies endêmicas de ostracodes. Tenedocythere trindadensis sp. nov., uma espécie também registrada na plataforma equatorial do Brasil, é aqui descrita e ilustrada.

Palavras-chave: ilhas oceânicas, ostracodes, Atol das Rocas, Ilha da Trindade, zoogeografia, paleozoogeografia.

\section{INTRODUCTION}

Physical isolation is conducive to allopatric speciation and thus responsible for generally high levels of endemism. One of the many causes of isolation is the imposition of barriers, such as seaways for terrestrial and freshwater organisms, or land masses for the marine taxa. The deep ocean, in turn, constitutes a barrier to the dispersal of benthic invertebrates with life cycles restricted to shallow waters on the continental shelf. In the case of oceanic islands, it is expected that areas consistently isolated over millions of years have higher levels of endemism than those with continual or intermittent shallow submarine connections with the mainland or other islands (Larwood \& Whatley, 1993). Oceanic islands typically harbor low species richness and a high proportion of endemic reef fish and benthic species owing to their extreme isolation and relatively restricted shallow water zones (Whittaker \& Fernandez-Palacios, 2007).
Benthic marine shallow water Ostracoda is a key group since it does not possesses a planktotrophic larval stage and most marine species are not good swimmers.

Together with São Pedro and São Paulo Rocks, Fernando de Noronha Archipelago and Martin Vaz Island, the Rocas Atoll and Trindade constitute the set of Brazilian oceanic islands. In 2002 the Brazilian Environmental Bureau declared the Trindade Island a highly important area for the conservation of marine animal and plant life due to its unique tropical Atlantic oceanic setting. However, recent studies indicate that the marine biota of Trindade is the least known among the five Brazilian oceanic islands and archipelagos (Alves \& Castro, 2006). Nevertheless, some studies have been undertaken in order to compile an inventory of the Trindade's biodiversity, for which mechanisms of conservation, protection, and management can be established. They have focused on both the flora (Joly, 1950; Pedrini, 1989; Nassar, 
1994; Alves \& Guimarães 1998; Yoneshigue-Valentin et al., 2005; Villaça et al., 2006) and fauna (Vannucci, 1950; Carvalho, 1950; Pinto, 1957; Lanzieri, 1966; Brito, 1971; Coelho, 1974; Breure \& Coelho 1976; Tavares, 1999; Moraes et al., 2006; Pinheiro et al., 2009; Pereira-Filho et al., 2011). Concerning the study of microfossils, with the exception of a brief report on foraminifers (Rodrigues, 1971) and a book chapter with preliminary data on ostracodes (Coimbra et al., 2009), microfossils groups have not been studied at Trindade.

Because Rocas is the only atoll in the Southwest Atlantic, and it is also one of the smallest in the world, it was declared as a Marine Biological Reserve in 1979 and recognized as a UNESCO Worldwide Heritage Site, in 2001. Despite its importance, no micropalaeontological study has been carried out in the area with the exception of preliminary lists of foraminifers (Tinoco, 1965, 1972; Rossi et al., 1996), foraminifers and bryozoans (Machado \& Souza, 1994) and ostracodes (Coimbra et al., 2009).

The present study constitutes the most comprehensive study of the benthic shallow marine ostracode species in the Brazilian oceanic Trindade Island and Rocas Atoll, and represents a contribution to the modern and palaeo-zoogeographic knowledge of this group. It is focused on the species richness of these two ostracode faunas and on unraveling the distributional history of their taxa.

The study of Quaternary and late Neogene ostracodes from oceanic islands and archipelagos dates back to the nineteenth century, however intense research on such faunas developed only in the 1970 s. The first comprehensive study on this subject was undertaken at Clipperton Island in the tropical northeastern Pacific (Allison \& Holden, 1971). Such studies have not been numerous and most deals with Pacific or Indo-Pacific regions, the best known being in the Solomon Islands, southwestern Pacific Ocean (Whatley \& Titterton, 1981; Titterton \& Whatley, 1988a,b, 2005, 2006a,b, 2007, 2008, 2009a,b, 2010); the Galapagos Islands, tropical southeastern Pacific (Pokorný, 1970, 1972; Bate et al., 1981); in French Polynesia, tropical central Pacific (Hartmann, 1984); at some atolls and a few larger islands in Micronesia, western equatorial Pacific (Weissleader et al., 1989); at Réunion Island, southern Indian Ocean (Whatley \& Keeler, 1989); at Easter Island, southeastern Pacific Ocean (Whatley \& Jones, 1999; Whatley, 2000; Whatley et al., 2000); at Bermuda, western North Atlantic Ocean (Keyser \& Schöning, 2000); at Marion/Prince Edward islands, sub-Antarctic Indian Ocean (Dingle, 2002, 2003); in the Cape Verde Archipelago, tropical eastern Atlantic Ocean (Wouters, 2003); in the Mariana Islands, western equatorial Pacific (Paulay et al., 2003); at Pitcairn, Oeno and Henderson islands, southern Pacific (Whatley et al., 2004); in the islands of New Caledonia, tropical southwestern Pacific (Maddocks, 2007); and a preliminary study in the São Pedro and São Paulo Archipelago, equatorial Atlantic (Antonietto et al., 2012). These studies mostly focused on the taxonomy and zoogeography (some of them including migration strategies and endemism) of ostracodes.

\section{STUDY AREAS}

\section{Trindade Island}

Trindade Island is somewhat elliptical, $2.5 \mathrm{~km}$ wide, and is located in the South Atlantic Ocean (20'30'S, $\left.29^{\circ} 18^{\prime} \mathrm{W}\right)$ around $1,170 \mathrm{~km}$ from the Brazilian coast, approximately at the same latitude as Vitória City, the capital of the Espírito Santo State (Figure 1). It is positioned on the Vitória-Trindade Alignment, which constitutes an E-W submarine volcanic chain with an inactive volcano lying at a depth of $5,500 \mathrm{~m}$ (Figure 2). The alignment extends east for $1,000 \mathrm{~km}$ from the seamount of Victoria, located near the southeast coast of Brazil, to the islands of Trindade and Martin Vaz. Volcanic activity spanned in time since the late Pliocene $(\sim 3.4 \mathrm{Ma})$ to the early Holocene, maintaining Trindade above the ocean surface (Almeida, 2002).

According to Thomaz Filho \& Rodriguez (1999), the Vitória-Trindade Alignment developed as a result of multiple magmatic events as the South American Plate moved over a hot-spot during its separation from the African plate. Trindade Island corresponds to an emergent part of one of the volcanic edifices (Ferrari \& Ricomini, 1999) with three peaks that rise to about $600 \mathrm{~m}$ above sea level. The island is surrounded by oceanic waters that reach 5,800 $\mathrm{m}$ depth. Most of the island consists of volcanic rocks apart from a small area with coastal sediments.

\section{Rocas Atoll}

Rocas Atoll has been described as a ring-like, semi-closed, elliptic reef, open at its western and southern limits, and is located $260 \mathrm{~km}$ east of Natal City and $145 \mathrm{~km}$ west of the Fernando de

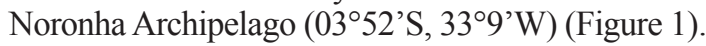

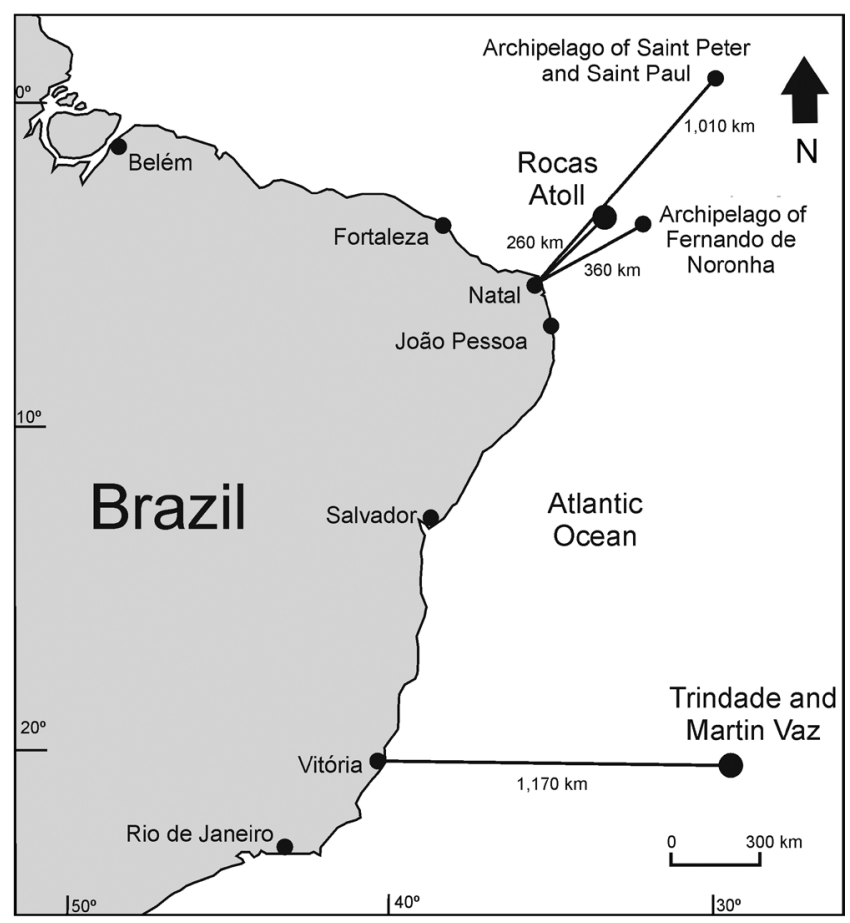

Figure 1. Location map of the Brazilian oceanic islands and archipelagos showing the distances to the nearest cities (modified from Almeida, 2006). 

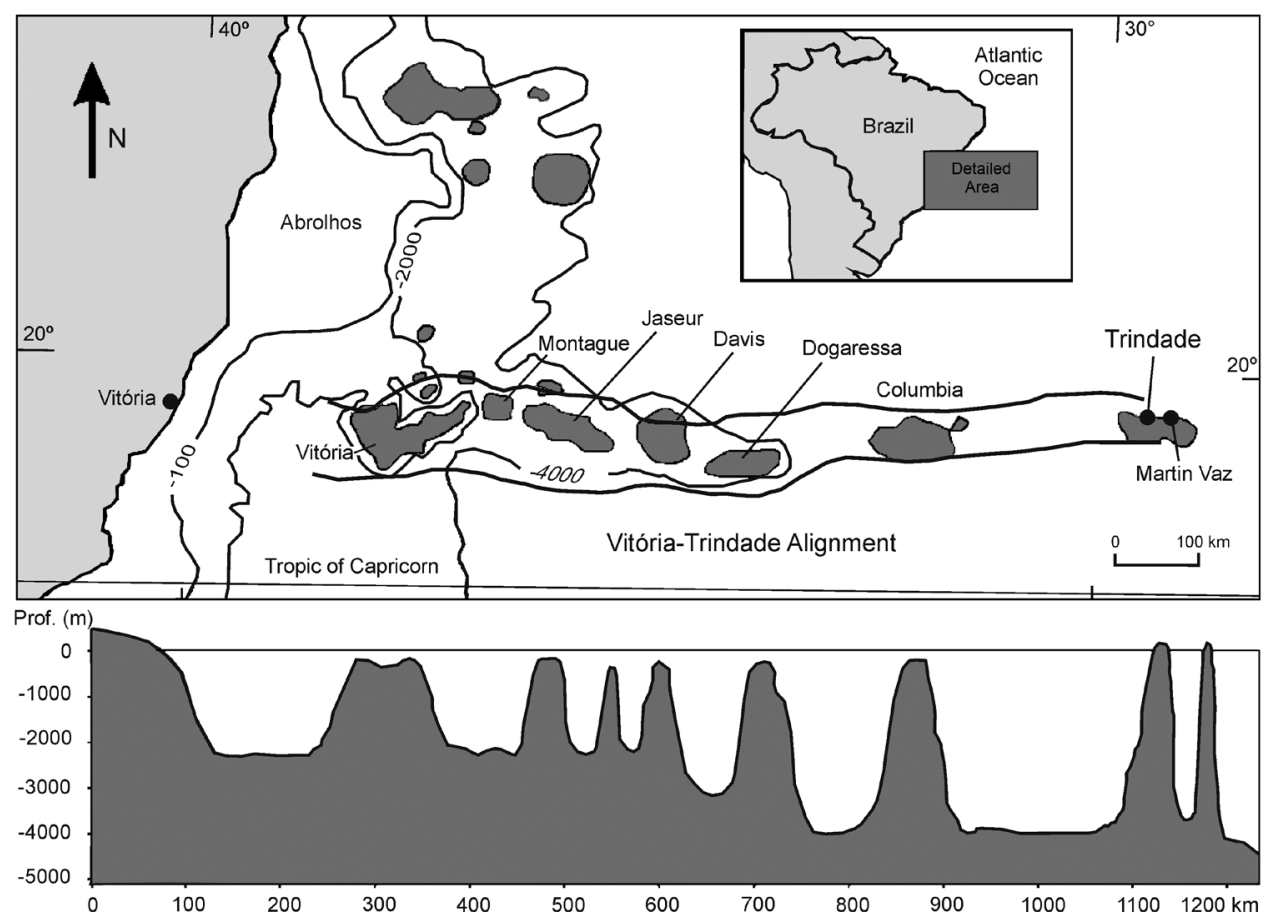

Figure 2. Geographical and bathymetrical map of the Vitória-Trindade Alignment and its seamounts (modified from Alves, 1998 and Almeida, 2006).

According to Almeida (1955, 2002, 2006), both the Fernando Noronha Archipelago and Rocas Atoll are part of a seamounts alignment developed along the Fernando de Noronha Fracture Zone of the meso-Atlantic Ridge (Figure 3). The volcanic rocks are covered by coralline algae, such as Porolithon, Lithophyllum, Sporolithon and Lithoporella, associated with vermetid gastropods and corals (Siderastrea stellata Verrill, 1868) and an abundant species of the encrusting foraminifera Homotrema rubrum (Lamarck, 1816).

\section{Oceanic circulation}

The cool Benguela Current runs northward along the African coast, flowing then westward creating the South Equatorial Current (SEC), which crosses the Atlantic

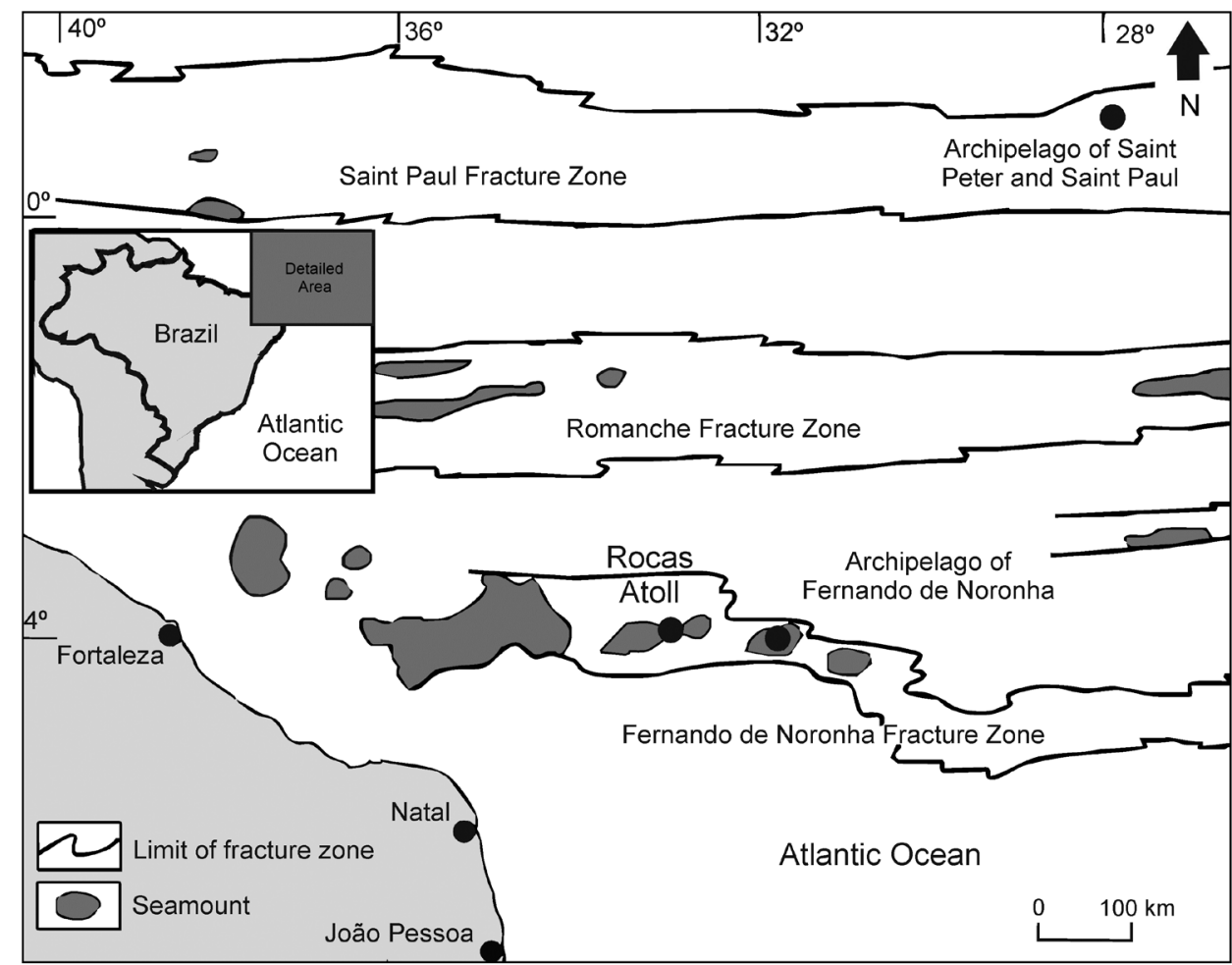

Figure 3. Map of the ocean area off the coast of NE Brazil, with some emphasis on the Fracture Zone of Fernando de Noronha and the Rocas Atoll (modified from Almeida, 2006). 
parallel to the Equator. The SEC is a broad, westward flowing current that extends from the surface to a nominal depth of $100 \mathrm{~m}$. Its northern boundary is usually near $4^{\circ} \mathrm{N}$, while the southern boundary is usually found between $15-25^{\circ} \mathrm{S}$, depending primarily on longitudinal location and the time of the year. It divides near to Brazilian coast $\left(10-14^{\circ} \mathrm{S}\right)$ generating the North Brazil Current (= Guyana Current), which runs along the equatorial margin, and the Brazil Current, which runs southward (Peterson \& Stramma, 1991) (Figure 4).

The region around Trindade Island is strongly influenced by the Brazil Current (salinity $\sim 37 \%$; $\mathrm{T}^{\circ} \sim 27^{\circ} \mathrm{C}$; transparency up to $50 \mathrm{~m} \mathrm{depth}$ ), presents tropical climate and temperatures around $25.2^{\circ} \mathrm{C}$ on average (February $30.2^{\circ} \mathrm{C}$, August $17.3^{\circ} \mathrm{C}$ ) with intermittent influence of cold fronts from the South Pole. The southwest trade winds are dominant, and the average annual precipitation is low (Alves, 1998).

Rocas Atoll is bathed by SEC. The ESE dominant winds blow during $45 \%$ of the year. Between June and August (winter), SE winds are recorded in $35 \%$ of the days while the frequency of the E winds is $15 \%$ in the same period. Between December and April (summer), SE and E winds occur during $20 \%$ of the days. The wind speed ranges from six to $10 \mathrm{~m} / \mathrm{s}$ on average during the year, but in the winter, speeds between 11 and $15 \mathrm{~m} / \mathrm{s}$ are common. Speeds above 20 $\mathrm{m} / \mathrm{s}$ have been recorded more frequently during the summer (Kikuchi, 2002).

The annual temperature varies between 17.5 and $35.8^{\circ} \mathrm{C}$, with a monthly pluvial regime average of $860 \mathrm{~mm}$; the average water temperature around the atoll is $27^{\circ} \mathrm{C}$, the minimum is $25.5^{\circ} \mathrm{C}$ and maximum of $28^{\circ} \mathrm{C}$ (Kikuchi, 2002).

\section{MATERIAL AND METHODS}

Surface sample details were registered according to location, depth, and sediment type (Table 1). All samples from Trindade Island, with the exception of sample M0200, which was collected by I.I. Leipnitz in 1990, were hand collected by the biologists C.P. Machado, N.G. Drozinski and V.G. Ghilardi with the help of the Brazilian marine crew, at the beginning of the first decade of the 21st century. At Rocas Atoll, samples were hand collected by the Brazilian marine crew, in 1992, at various depths from three transects located on the western side of the atoll.

The samples were washed and prepared for study following standard procedures for calcareous microfossils. The material was provided as dry sediment and each sample was sieved into three size fractions: $0.250,0.177$ and 0.063 $\mathrm{mm}$. All size fractions were thoroughly picked for Ostracoda, although the finest material was commonly barren. All photographs were taken at the Instituto de Ciencias del Mar y Limnología, Universidad Nacional Autónoma de Mexico (UNAM).

The ostracodes examined in this study are held in the collections of the 'Museu de Paleontologia', Universidade Federal do Rio Grande do Sul (UFRGS), Section of Ostracoda. The type material is identified by the prefix MP-O. This paper follows the suprageneric classification of Ostracoda by Liebau (2005).

\section{TAPHONOMY}

The sampling techniques used in this study did not permit the distinction between living and sub-Recent ostracodes,

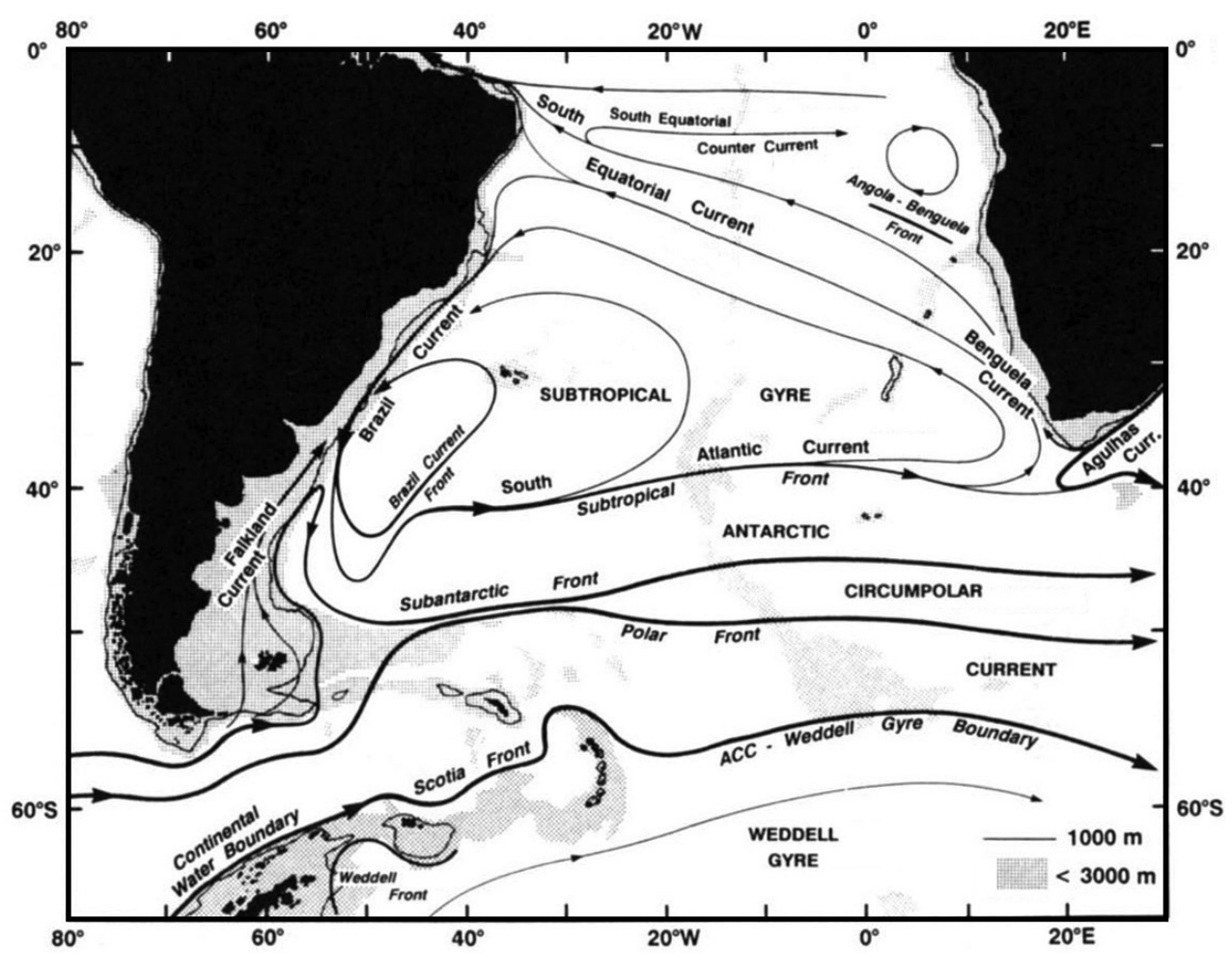

Figure 4. Surface circulation in the South Atlantic (modified from Peterson \& Stramma, 1991). 
Table 1. Number, location, depth, and sediment type of samples recovered from Trindade Island and Rocas Atoll, Brazil.

\begin{tabular}{|c|c|c|c|c|}
\hline Sample & Locality & Coordinates & Depth (m) & Sediment \\
\hline MO200 & Trindade, just on face of Andradas Beach & $20^{\circ} 30^{\prime} 33^{\prime \prime} \mathrm{S}-29^{\circ} 16^{\prime} 22^{\prime \prime} \mathrm{W}$ & 20 & fine to medium sand \\
\hline MO201 & Trindade. Parcel das Tartarugas Pool & $20^{\circ} 31^{\prime} 13^{\prime \prime} \mathrm{S}-29^{\circ} 17^{\prime} 59^{\prime \prime} \mathrm{W}$ & 1 & very fine sand \\
\hline MO202 & Trindade. Crista do Galo Pool & $20^{\circ} 29^{\prime} 13^{\prime \prime} \mathrm{S}-29^{\circ} 20^{\prime} 16^{\prime \prime} \mathrm{W}$ & 1 & very fine sand \\
\hline MO203 & Trindade. Calheta Beach & $20^{\circ} 30^{\prime} 30^{\prime \prime} \mathrm{S}-29^{\circ} 18^{\prime} 33^{\prime \prime} \mathrm{W}$ & 1 & medium sand \\
\hline MO204 & Trindade. Calheta Beach & $20^{\circ} 30^{\prime} 31^{\prime \prime S}-29^{\circ} 18^{\prime} 32^{\prime \prime} \mathrm{W}$ & 7 & medium sand \\
\hline MO205 & Trindade. Calheta Beach & $20^{\circ} 30^{\prime} 36^{\prime \prime} \mathrm{S}-29^{\circ} 18^{\prime} 26^{\prime \prime} \mathrm{W}$ & 10 & medium sand \\
\hline MO206 & Trindade. Calheta Beach & $20^{\circ} 30^{\prime} 38^{\prime \prime} \mathrm{S}-29^{\circ} 48^{\prime} 27^{\prime \prime} \mathrm{W}$ & 15 & medium sand \\
\hline MO207 & Trindade. Andradas Beach & $20^{\circ} 30^{\prime} 42^{\prime \prime} \mathrm{S}-29^{\circ} 18^{\prime} 23^{\prime \prime} \mathrm{W}$ & 3 & medium sand \\
\hline MO208 & Trindade. Andradas Beach & $20^{\circ} 30^{\prime} 47^{\prime \prime} \mathrm{S}-29^{\circ} 18^{\prime} 21^{\prime \prime} \mathrm{W}$ & 3 & medium sand \\
\hline MO209 & Trindade. Tartarugas Beach & $20^{\circ} 31^{\prime} 04^{\prime \prime} \mathrm{S}-29^{\circ} 18^{\prime} 02^{\prime \prime} \mathrm{W}$ & 1 & medium sand \\
\hline MO210 & Trindade. Túnel Beach & $20^{\circ} 31^{\prime} 31^{\prime \prime} \mathrm{S}-29^{\circ} 17^{\prime} 58^{\prime \prime} \mathrm{W}$ & 1 & coarse sand \\
\hline MO307 & Rocas Atoll. Transect A & $3^{\circ} 51^{\prime} 08.2^{\prime \prime} \mathrm{S}-30^{\circ} 49^{\prime} 19.32^{\prime \prime} \mathrm{W}$ & 10 & gravel \\
\hline MO308 & Rocas Atoll. Transect A & $3^{\circ} 51^{\prime} 00^{\prime \prime} \mathrm{S}-30^{\circ} 49^{\prime} 21.35^{\prime \prime} \mathrm{W}$ & 18 & coarse sand \\
\hline MO309 & Rocas Atoll. Transect A & $3^{\circ} 50^{\prime} 49.75^{\prime \prime} \mathrm{S}-30^{\circ} 49^{\prime} 35.6^{\prime \prime} \mathrm{W}$ & 27 & very coarse sand and gravel \\
\hline MO310 & Rocas Atoll. Transect B & $3^{\circ} 52^{\prime} 17.29^{\prime \prime} \mathrm{S}-30^{\circ} 49^{\prime} 39.7^{\prime \prime} \mathrm{W}$ & 10 & gravel \\
\hline MO311 & Rocas Atoll. Transect B & $3^{\circ} 52^{\prime} 24.91^{\prime \prime} \mathrm{S}-30^{\circ} 49^{\prime} 39.7^{\prime \prime} \mathrm{W}$ & 20 & coarse sand \\
\hline MO312 & Rocas Atoll. Transect B & $3^{\circ} 52^{\prime} 33.05^{\prime \prime} \mathrm{S}-30^{\circ} 49^{\prime} 48.8^{\prime \prime} \mathrm{W}$ & 30 & gravel \\
\hline MO313 & Rocas Atoll. Transect C & $3^{\circ} 51^{\prime} 32.82^{\prime \prime} \mathrm{S}-30^{\circ} 49^{\prime} 39.7^{\prime \prime} \mathrm{W}$ & 10 & coarse sand \\
\hline MO314 & Rocas Atoll. Transect C & $3^{\circ} 51^{\prime} 32.82^{\prime \prime} \mathrm{S}-30^{\circ} 49^{\prime} 50.3^{\prime \prime} \mathrm{W}$ & 20 & coarse sand \\
\hline MO315 & Rocas Atoll. Transect C & $3^{\circ} 51^{\prime} 32.82^{\prime} \mathrm{S}-30^{\circ} 50^{\prime} 05.1^{\prime \prime} \mathrm{W}$ & 27 & coarse sand \\
\hline
\end{tabular}

since only empty carapaces and valves were obtained. Although the authors do not ignore the possibility of bias introduced by time-averaging in marine accumulations, they are unaware of studies on this topic done using marine benthic ostracodes. However, some analysis based on larger bivalve invertebrates, such as mollusks and brachiopods recovered from tropical and sub-tropical shallow-water samples of unconsolidated surficial deposits, has revealed that shells can range in age from modern to 4,000 yr B.P. (Kowalewski et al., 1994, 1998, 2000, 2002). Carroll et al. (2003), in a study on empty shells and valves of the terebratulid Bouchardia rosea (Mawe, 1823) recovered from the inner shelf off São Paulo State, dated specimens from modern to 3,000 yr B.P, with a standard deviation of 690 years, and so concluded that time-averaging in such accumulations varied from hundreds to thousands of years. The estimates of time-averaging differed greatly among the study sites, with an age range of 370 years at the least time-averaged locality and over 3,200 years at the most time-averaged locality. Finally, Krause et al. (2010) dated 178 shells collected from two sites on a mixed carbonate-siliciclastic shelf off the coast of SE Brazil where the brachiopod B. rosea and the bivalve Semele casali DoelloJurado, 1949 were dominant components of the local fauna. The material ranged in age from zero (not lived collected) to 8,118 yr B.P., but $83 \%$ of them were from the last 3,000 years.

Moreover, regarding the transport of dead shells and valves, biostratinomic studies have demonstrated clearly that transport of macrobenthic shells (e.g. Carroll et al., 2003 and references therein), or even microscopic tests of foraminifers (Be'\& Hutson, 1977; Martin, 1999), is limited in marine environments, even in high-energy, shallow-water settings. Carroll et al. (2003) identified substantial lack of transport, even by direct observations, as follows: "the brachiopod shells occur in patches and are found primarily in those areas where live specimens are present. They represent in situ accumulations produced by local populations, and not transported material."

According to the above discussion and on biostratinomic inferences based on assemblages of Ostracoda performed by Van Morkhoven (1972), Whatley (1983), Brouwers (1988), Whatley \& Boomer (1995) and Coimbra et al. (1999b), the present authors concluded that the analysis of the total fauna of dry bottom sediments recovered from the Trindade Island and Rocas Atoll, is an appropriate option to perform estimation of species richness and zoogeographical and palaeozoogeographical analysis. In fact, it also presents some advantages over the study of exclusively living faunas: (i) it offers good ecological interpretations due to the greater number of specimens available; (ii) it eliminates the possibility of fluctuations in the composition of the fauna which results, for example, from seasonal variability; (iii) it allows a more direct comparison between Recent and fossil assemblages.

\section{FAUNAL ANALYSIS}

Similarly to other Brazilian oceanic islands, these two study islands possess poorly diversified reef fish and benthic assemblages, possibly due to its isolation and small size in comparison to the mainland (Floeter et al., 2008; PereiraFilho et. al., 2011). The same statement is also true for the present study, where a relatively low richness and abundance of benthic ostracodes were registered. However, it differs from studies based on other zoological groups by the apparent 
absence of endemic species. Samples M0203, M0204, M0209 and M0210 were barren for ostracodes but 21 species were recorded from the remaining samples. Due to the scarcity of adult specimens, five species were left in open nomenclature and at least two ones were identified only to Bairdiidae. With the exception of the three species of Caudites, the other genera recorded are monospecific.

The diversity and abundance of ostracodes at Rocas Atoll was also comparatively low and no endemic species were recovered so far. Samples MO310 and MO313 were barren. Twenty-five species were recorded from the remaining seven samples. Fifteen species were confidently identified and the remainder left in open nomenclature.

The number of valves and carapaces of each species in each sample are given in the Tables 2 and 3. Assemblages from both localities contain very common shallow water pandemic species, such as Triebelina sertata Triebel, 1948 and Kotarocythere inconspicua (Brady, 1880) as well as Tenedocythere ex gr. transoceanica (Teeter, 1975), which are considered to have originated in the Indo-Pacific Ocean, but are nowadays widely distributed in shallow tropical marine shelves, including part of the Brazilian shelf (Coimbra et $a l .$, 1999b) and the Tamandaré Bay in northeastern Brazil (Coimbra et al., 1992). On the other hand, Keijia demissa Teeter, 1975, Neomonoceratina mediterranea (Ruggieri, 1953) and Kangarina abyssicola (Müller, 1894), also wellknown warm-water pandemic ostracodes with records on the Brazilian tropical shelf (Coimbra et al., 1999b), are unexpectedly absent both from Trindade and Rocas.
Species largely considered to be typically Caribbean [Glyptobairdia coronata (Brady, 1870), Caudites obliquecostatus Bold, 1963, and Radimella confragosa (Edwards, 1944)] were recorded at one or both islands (Tables $2,3)$. These taxa have all been reported previously in Brazil (Coimbra et al., 1992, 1999b). Paracytheridea tschoppi Bold, 1946, a Miocene species that nowadays has a wide distribution in the Atlantic and is also present in the East and West Pacific oceans and in some oceanic islands, such as Clipperton, Solomon and Réunion, and Hemicytherura bradyi (Puri, 1960), a species reported since the upper Miocene in the Caribbean, Gulf of Mexico and Florida, were also recorded in the studied samples. They are also represented by few specimens in Holocene sediments from the equatorial shelf of Brazil as discussed by Coimbra et al. (1999a,b).

Among the other species recorded from Trindade, Caudites exmouthensis Hartmann 1978 and Caudites seminudus Whatley $\&$ Keeler, 1989, both assumed to have originated in the IndoPacific Ocean, are scarce and are also sparsely distributed in Holocene sediments from Tamandaré Bay, northeastern Brazil (Coimbra et al., 1992). Auradilus costatus (Hu, 1979), described from the Pleistocene of Taiwan and with living populations in the Indian and Pacific oceans, is also present at Trindade Island and has been reported along the Brazilian equatorial and northeastern shelves and in Tamandaré and Sepetiba bays (Fauth \& Coimbra, 1998; Coimbra et al., 1999b).

A few carapaces (three) and valves (five) of Australimoosella polypleuron Coimbra et al., 2004, whose genus is more diversified in the Pacific Ocean, were recovered from Trindade

Table 2. Occurrence and abundance of ostracode species recorded at Trindade Island. Abbreviations: c, carapace; v, valve.

\begin{tabular}{|c|c|c|c|c|c|c|c|}
\hline \multirow{2}{*}{ Species } & \multicolumn{7}{|c|}{ Samples } \\
\hline & MO200 & MO201 & MO202 & MO205 & MO206 & MO207 & MO208 \\
\hline Auradilus costatus & $1 \mathrm{c}, 2 \mathrm{v}$ & & & & & & \\
\hline Australimoosella polypleuron & $3 \mathrm{c}, 5 \mathrm{v}$ & & & & & & \\
\hline Bairdiidae indet. 1 & $3 \mathrm{v}$ & & & $1 \mathrm{v}$ & $1 \mathrm{v}$ & & \\
\hline Bairdiidae indet. 2 & $2 \mathrm{c}, 8 \mathrm{v}$ & $3 v$ & & & & & \\
\hline Caudites exmounthesis & $1 \mathrm{c}, 1 \mathrm{v}$ & & & & & & \\
\hline Caudites obliquecostatus & $1 \mathrm{c}$ & $3 \mathrm{v}$ & $4 v$ & & & & \\
\hline Caudites seminudus & $4 c, 2 v$ & $7 \mathrm{c}, 21 \mathrm{v}$ & $3 c$ & $4 v$ & & $1 \mathrm{v}$ & $4 \mathrm{c}$ \\
\hline Hemicytherura bradyi & & $1 \mathrm{v}$ & & $1 \mathrm{v}$ & & $1 \mathrm{v}$ & $1 \mathrm{c}$ \\
\hline Keijcyoidea sp. & $8 \mathrm{c}, 19 \mathrm{v}$ & $1 \mathrm{c}, 6 \mathrm{v}$ & & & & $1 \mathrm{v}$ & $2 \mathrm{v}$ \\
\hline Kotarocythere inconspicua & & $2 \mathrm{c}, 1 \mathrm{v}$ & & $2 \mathrm{c}, 2 \mathrm{v}$ & $2 \mathrm{c}$ & & \\
\hline Loxoconcha bullata & $6 c, 214 v$ & $6 \mathrm{v}$ & $1 \mathrm{v}$ & $2 v$ & & & \\
\hline Macrocyprina $\mathrm{sp}$. & $1 \mathrm{c}, 13 \mathrm{v}$ & & & & & & \\
\hline Nanocoquimba labyrinthica & $5 \mathrm{c}$ & & & & & & $3 \mathrm{c}, 1 \mathrm{v}$ \\
\hline Paracypris sp. & & & & $2 \mathrm{c}, 1 \mathrm{v}$ & & $1 \mathrm{c}$ & \\
\hline Paracytheridea tschoppi & $533 \mathrm{v}$ & $14 \mathrm{v}$ & $1 \mathrm{v}$ & $4 v$ & $1 \mathrm{v}$ & & $3 v$ \\
\hline Paranesidea parabipustulosa & $2 \mathrm{c}, 8 \mathrm{v}$ & & & & & & \\
\hline Puriana variabilis & $4 \mathrm{c}, 8 \mathrm{v}$ & & & & & & \\
\hline Sclerochilus sp. & & $1 \mathrm{c}, 5 \mathrm{v}$ & & & & & \\
\hline Tenedocythere trindadensis & $78 \mathrm{c}, 93 \mathrm{v}$ & $9 \mathrm{v}$ & & $1 \mathrm{v}, 4 \mathrm{v}$ & $2 \mathrm{v}$ & & $1 \mathrm{v}$ \\
\hline Triebelina sertata & $20 \mathrm{v}$ & $1 \mathrm{v}$ & & & & $1 \mathrm{v}$ & $1 \mathrm{v}$ \\
\hline Xestoleberis sp. & $1 \mathrm{c}, 10 \mathrm{v}$ & $1 \mathrm{v}$ & $2 v$ & $21 \mathrm{v}$ & & & \\
\hline
\end{tabular}


Table 3. Occurrence and abundance of ostracode species recorded at Rocas Atoll. Abbreviations: c, carapace; v, valve.

\begin{tabular}{|c|c|c|c|c|c|c|c|}
\hline \multirow{2}{*}{ Species } & \multicolumn{7}{|c|}{ Samples } \\
\hline & MO307 & MO308 & MO309 & MO311 & MO312 & MO314 & MO315 \\
\hline Caudites seminudus & $1 \mathrm{c}$ & & $1 \mathrm{v}$ & $2 \mathrm{v}$ & & & \\
\hline Caudtes sp. & $5 \mathrm{c}, 6 \mathrm{v}$ & & $1 \mathrm{c}, 1 \mathrm{v}$ & & $1 \mathrm{v}$ & & \\
\hline Cytherura sp. & & & & $1 \mathrm{v}$ & & & \\
\hline Glyptobairdia coronata & $4 v$ & & $1 \mathrm{v}$ & & & $1 \mathrm{v}$ & $2 \mathrm{c}, 2 \mathrm{v}$ \\
\hline Hemicytherura bradyi & & & $1 \mathrm{v}$ & $1 \mathrm{c}, 8 \mathrm{v}$ & & & \\
\hline Keijcyoidea amazonica & $6 \mathrm{v}$ & $1 \mathrm{v}$ & $5 v$ & & & $1 \mathrm{c}, 1 \mathrm{v}$ & $1 \mathrm{c}, 1 \mathrm{v}$ \\
\hline Kotarocythere inconspicua & & & $4 v$ & $7 \mathrm{c}, 8 \mathrm{v}$ & & & $1 \mathrm{c}$ \\
\hline Loxoconcha sp. & $6 \mathrm{v}$ & & & & & & \\
\hline Loxocorniculum tricornatum & $1 \mathrm{c}, 10 \mathrm{v}$ & & $12 \mathrm{v}$ & $5 \mathrm{v}$ & $4 v$ & & $4 \mathrm{c}$ \\
\hline Macrocyprina sp. & & $1 \mathrm{v}$ & $2 \mathrm{c}, 1 \mathrm{v}$ & $1 \mathrm{v}$ & $1 \mathrm{c}, 2 \mathrm{v}$ & & $2 \mathrm{v}$ \\
\hline Neocaudites subimpressus & & & & & & & $1 \mathrm{c}$ \\
\hline Neonesidea sp.1 & & & & & $6 v$ & $2 v$ & \\
\hline Neonesidea? spp. & $13 \mathrm{v}$ & $3 \mathrm{c}, 2 \mathrm{v}$ & $11 \mathrm{v}$ & $2 \mathrm{v}, 9 \mathrm{v}$ & $2 \mathrm{v}$ & $1 \mathrm{c}, 13 \mathrm{v}$ & $5 c, 15 \mathrm{v}$ \\
\hline Orionina bradyi & & & $1 \mathrm{c}$ & & $1 \mathrm{c}$ & & \\
\hline Paracytheridea batei & $2 \mathrm{v}$ & $1 \mathrm{v}$ & $18 \mathrm{v}$ & $2 \mathrm{v}$ & $1 \mathrm{v}$ & & \\
\hline Pellucistoma sp. & & & $3 \mathrm{v}$ & & & & \\
\hline Puriana convoluta & $1 \mathrm{c}, 1 \mathrm{v}$ & & $4 v$ & $2 \mathrm{v}$ & & & $1 \mathrm{c}$ \\
\hline Radimella confragosa & $1 \mathrm{v}$ & $1 \mathrm{c}$ & $2 \mathrm{c}, 1 \mathrm{v}$ & & & & $1 \mathrm{c}, 1 \mathrm{v}$ \\
\hline Tenedocythere ex gr. transoceanica & $20 \mathrm{v}$ & & $2 \mathrm{c}, 10 \mathrm{v}$ & $5 \mathrm{v}$ & $2 \mathrm{v}$ & & $1 \mathrm{c}, 1 \mathrm{v}$ \\
\hline Tenedocythere trindadensis & $4 c, 2 v$ & $1 \mathrm{c}$ & $1 \mathrm{c}$ & & $1 \mathrm{v}$ & $1 \mathrm{c}$ & $1 \mathrm{c}, 1 \mathrm{v}$ \\
\hline Triebelina sertata & $2 \mathrm{v}$ & & $1 \mathrm{v}$ & & & & $2 \mathrm{v}, 1 \mathrm{v}$ \\
\hline Xestoleberis spp. & $1 \mathrm{c}, 6 \mathrm{v}$ & $3 \mathrm{v}$ & $8 \mathrm{c}, 38 \mathrm{v}$ & $9 \mathrm{c}, 24 \mathrm{v}$ & $3 \mathrm{c}, 3 \mathrm{v}$ & $2 \mathrm{c}, 3 \mathrm{v}$ & $5 \mathrm{c}, 2 \mathrm{v}$ \\
\hline
\end{tabular}

Island, constituting just the second record of this genus (and species) in the Atlantic Ocean; its extremely low abundance did not allow confident explanation of its presence. Coimbra et al. (2009) tentatively proposed that this genus, which has few species, migrated from an origin in the Australian region (see Hartmann, 1978) during the Quaternary. Nevertheless, the currently documented distribution of Australimoosella detracts from resolving an obvious migration route or mechanism. The same applies to the all species above mentioned whose origin is in the Indo-Pacific Ocean. A likely explanation is that these ostracodes arrived at these islands from the east (Indian and Pacific oceans) on floating algae, their holdfasts and attached sediments through a process of island hopping during times of low sea level. This hypothesis is reinforced by both the oceanic currents and wind flow pattern (see above Ocean circulation) in South Atlantic. Such a mechanism is discussed by Machado et al. (2005) in the study of the ecology and distribution of ostracodes in Rio de Janeiro inner shelf. Notwithstanding the wide distribution of many pandemic shallow marine ostracodes since the Neogene, some authors have inferred that recent human shipping has played an important role in the passive dispersal of these microcrustaceans (Witte \& Van Harten, 1991).

In general, as above discussed, the ostracode assemblage recovered in the present study consists of species that have been most frequently reported on the equatorial and/or northeastern Brazilian shelves. However, Nanocoquimba labyrinthica Ramos, 1996 and Loxoconcha bullata Hartmann,
1956, two species recorded at Trindade Island, were previously known only from the southeast and southern Brazil (see Ramos, 1996; Coimbra et al. 2006, 2007).

\section{TAXONOMY}

The identity of a few species recovered in this study is unsolved, leaving some uncertainty regarding their distribution and biogeographic affinities. One such case is Tenedocythere ex gr. transoceanica, a relatively abundant species at Rocas Atoll. Although Teeter (1975) and Cronin (1988) regarded this widely dispersed ostracode as morphologically welldefined, Cronin (1988, pl. 1, figs. 1-8) illustrated a slightly but conspicuous morphological variability among specimens from different populations around the world. Additionally, the circumtropical species Kotarocythere inconspicua shows no geographical variations, but it is a polymorphic ostracode with morphotypes that may occur sympatrically. According to Witte \& Van Harten (1991) it is a conspicuous species whose polymorphism has brought some confusion to systematics and zoo- and palaeozoogeography. Finally, Auradilus costatus (Hu, 1979), the only known species of this genus in waters beyond the Indian and Pacific oceans (Jellinek, 1995), was considered by Mostafawi et al. (2005) as a junior synonym of Auradilus convolutus (Brady, 1868), although in the opinion of the present authors they should be considered as distinct taxa.

Most species reported herein have been thoroughly described elsewhere; therefore, only a complete checklist is 
provided in Appendix 1. Because of the scarcity of specimens, poor preservation, and/or presence of only juvenile valves or carapaces, it was not possible to identify some forms at specific level and, therefore, they are listed under open nomenclature. Further works in the two study sites might bring additional data to elucidate some taxonomic aspects still poorly understood on Brazilian island ostracode faunas.

Order PODOCOPIDA Sars, 1866

Suborder CYTHEROCOPINA Gründel, 1967

Infraorder NOMOCYTHERININA Liebau, 1991

Superfamily TRACHYLEBERIDOIDEA Liebau, 2005

Family HEMICYTHERIDAE Puri, 1953

Subfamily THAEROCYTHERINAE Hazel, 1967

Tenedocythere Sissingh, 1972

Type species. Cythere prava Baird 1850. Holocene, Buzzards Bay, southeastern Massachusetts, USA.

Remarks. Although there is debate on the affinities of Tenedocythere with Quadracythere Hornibrook 1952, the latter lacks the well-developed ribs typical of the former. On the other hand, some authors (e.g. Titterton \& Whatley, 2008) consider Bosasella Bonaduce 1985, Neohornibrookella Jellinek, 1993 and Paraquadracythere Jellinek, 1993 to be junior synonyms of Tenedocythere. However, we consider that the morphologies of these taxa require further investigation before their synonymy can be justified. Finally, the real taxonomic status and relationships among the problematic genera Jugosocythereis Puri, 1957 and Quadracythere and Tenedocythere was not resolved by Titterton \& Whatley (2008), although Jugosocythereis possess some internal features that distinguish it from the other genera.

Tenedocythere trindadensis sp. nov.

(Figures 5A-L; Table 4)

1999b Hermanites transoceanicus Teeter. Coimbra, Pinto, Würdig \& Carmo, p. 370, pl. 2, fig. 3.

[non] 1975 Hermanites transoceanicus Teeter, p. 450, figs. 11o-q, $12 \mathrm{~h}$.

2009 Tenedocythere? sp. Coimbra, Ghilardi, Casetta \& Bergue, p. 136, fig. 5.1r.

Table 4. Morphometric data ( $\mathrm{mm}$ ) for Tenedocythere trindadensis sp. nov.

\begin{tabular}{lccc}
\hline \multicolumn{1}{c}{ Specimen } & Length & Height & Width \\
\hline MP-O-2402 Female LV & 0.52 & 0.34 & - \\
MP-O-2403 Female RV & 0.50 & 0.31 & - \\
MP-O-2404 Female C & 0.50 & 0.34 & 0.29 \\
MP-O-2405 Female LV & 0.50 & 0.31 & - \\
MP-O-2406 Female RV & 0.52 & 0.34 & - \\
MP-O-2407 Male? C & 0.50 & 0.28 & 0.28 \\
MP-O-2408 Female C & 0.52 & 0.32 & 0.29 \\
MP-O-2409 Female C & 0.52 & 0.33 & 0.29 \\
MP-O-2410 Female C & 0.52 & 0.34 & 0.29 \\
\hline
\end{tabular}

Type material. Holotype, MP-O-2402. Paratypes, MP-O2403 to 2410 . All type material is deposited in the collections of the 'Museu de Paleontologia', Universidade Federal do Rio Grande do Sul (UFRGS), Section of Ostracoda.

Type locality. Piscina Crista do Galo, $1 \mathrm{~m}$ water depth, sample MO200 (20²9'13'S-29²0'16”W). Very fine sand, Trindade Island, Brazil.

Additional material. Trindade Island: 78 carapaces and 110 valves; Rocas Atoll: three carapaces and 38 valves. See Tables 2 and 3.

Etymology. From the type locality, Trindade Island.

Diagnosis. Medium size. Surface with well-developed ornament of rounded to ovate fossae, somewhat subquadrate in dorsal, ventral and anterior regions. Ribs scarce and mainly oblique; ventro-lateral rib posteriorly alate. A well-defined wing-like process protrudes on the postero-dorsal margin. Eye tubercle conspicuous and crossed by the antero-marginal rib. Description. Medium-size carapace. Sub-rectangular in lateral view; greatest height at the anterior cardinal angle; greatest width just after mid-length in the swelling area. Subcentrally, a smooth swelling slightly antero-ventral in position. Eye tubercle conspicuous. Dorsal margin straight and inclined towards the posterior where it is largely obscured by a lateral wing-like process. Anterior margin broadly and slightly asymmetrically rounded with a well-developed flange more visibly plicate in the ventral half. Posterior margin laterally compressed, concave above, sub-acute and truncated sub-ventrally with five to six, short, strong and commonly broken spines. Ventral margin straight with distinct anteromedian concavity, partially hidden by a ventro-lateral alate rib. Surface covered with rounded to ovate fossae, somewhat subquadrate in dorsal, ventral and anterior regions. Sieve-type normal pores. An antero-marginal rib begins at the anterior cardinal angle, crosses the eye tubercle and runs parallel to the anterior margin being mid-ventrally very tenuous and ending in the antero-ventral margin. A somewhat blade-like dorsal rib runs parallel to the margin from the eye tubercle to the posterior cardinal angle where it forms a well-developed lateral wing-like process; ventral-lateral rib posteriorly alate. A rounded rib diverges from the dorsal rib, approximately at $1 / 3$ from the posterior cardinal angle, and runs obliquely downwards passing above the subcentral weakly developed swelling and ending almost anterior to it. A second more delicate but conspicuous rib diverges from the antero-ventral margin and runs upward in a curved path and just anterior to the subcentral swelling abruptly recurves, crossing the swelling, and continues straight ending approximately at $1 / 4$ before the posterior margin. Ornamentation less developed in $\mathrm{RV}$ than in LV. In dorsal view, carapace moderately inflated. Internally, RV hinge has a strong triangular anterior tooth and a deep post-adjacent socket with a medial smooth groove ending in an oval knob-like posterior tooth. Adductor muscle scar pattern consists of a slightly oblique row of four elongate scars with two frontal smaller and ovate scars, situated in the subcentral depression. In LV, muscle scars slightly obscured and situated in a more antero-ventral position. Radial pore canals straight, simple and numerous. Inner lamella broad, 


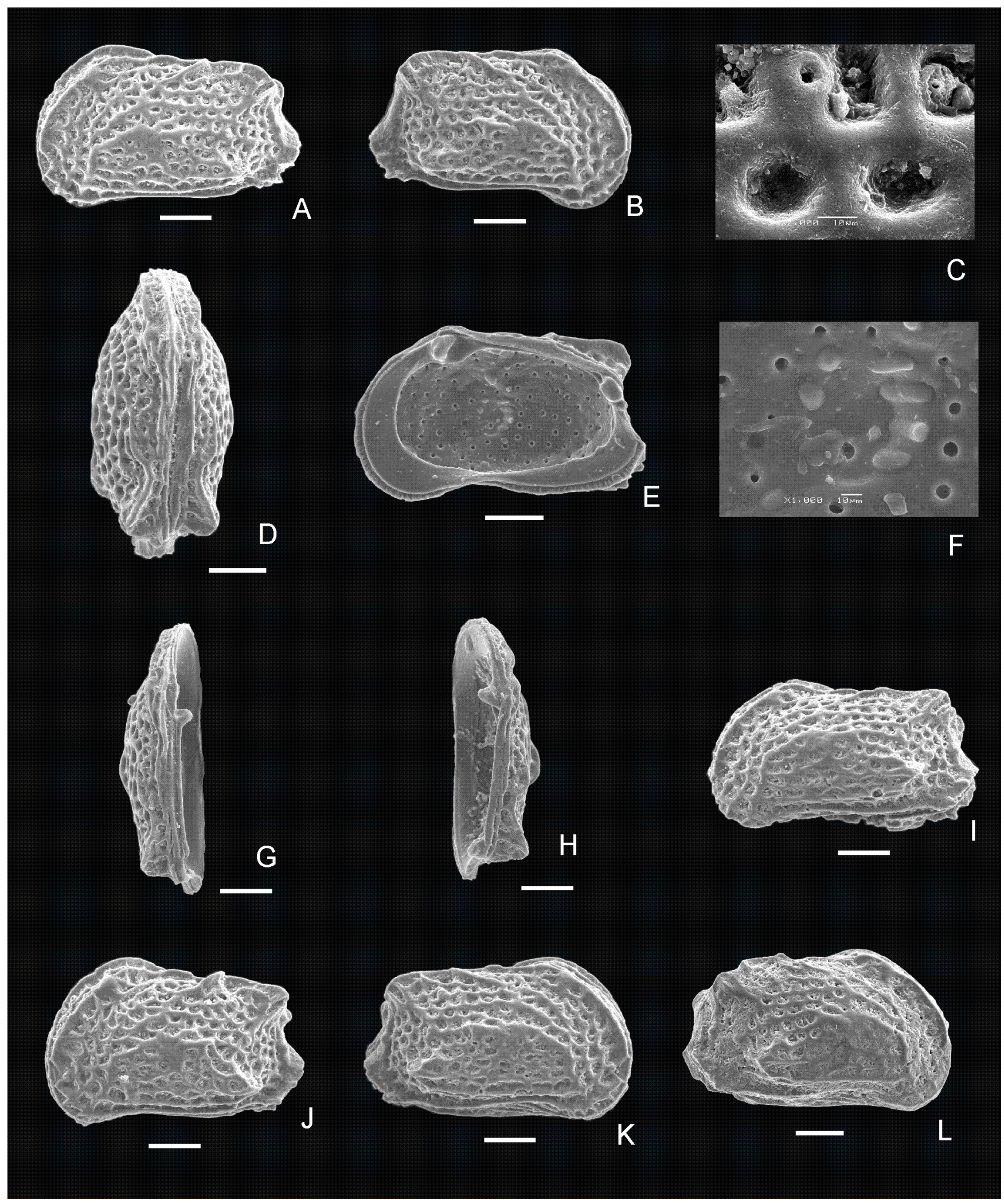

Figure 5. Specimens from Trindade Island, sample MO200. A-L, Tenedocythere trindadensis sp. nov. A, C, MP-O-2402, holotype, female left valve; A, external lateral view; C, detail of an intramural normal pore and a sieve-pore on solum. B, E, F, MP-O-2403, paratype, female right valve; B, external lateral view; E, internal lateral view; F, detail of the central muscle scars. D, MP-O-2404, paratype, female carapace, dorsal view. G, MP-O-2405, paratype, hinge of a female left valve, dorsal view. H, MP-O-2406, paratype, hinge of a female right valve, dorsal view. I, MP-O-2407, paratype, male? carapace, left lateral view. J, MP-O-2408, female carapace, left lateral view. Specimen showing second central low rib short and slightly sinuous. K, MP-O-2409, female carapace, right lateral view. Specimen showing second central low rib running long and straight before reaching the subcentral tubercle. L, MP-O-2410, paratype, female carapace, right lateral view, abraded specimen. Scale bars: $A, B, D, G, H, J, K=100 \mu \mathrm{m} ; C, F=10 \mu \mathrm{m} ; E=95 \mu \mathrm{m} ; \mathrm{I}, \mathrm{L}=90 \mu \mathrm{m}$. 
narrow ventrally and incurved, line of concrescence and inner margin coinciding throughout. Males more elongate than females and with few developed alar processes.

Geographical distribution. Besides its presence at Trindade Island and Rocas Atoll, this species was previously registered as Hermanites transoceanicus Teeter, 1975 based on a few specimens on the Brazilian equatorial shelf, but just to the southeast of the mouth of the Amazonas and Pará rivers (see Coimbra et al., 1999b).

Remarks. This species was previously identified by Coimbra et al. (1999b) as Hermanites transoceanicus and by Coimbra et al. (2009) as Tenedocythere? sp. According to Whatley \& Roberts (1995), Whatley et al. (2004) and Titterton \& Whatley (2008), H. transoceanicus possesses internal and external morphological features that make it better assigned to Tenedocythere. However, based on the morphological variation expressed by this species, as shown in the zoo- and palaeozoogeographic study by Cronin (1988, pl. 1, figs. 1-8), and in the opinion of the present authors, assignment to Tenedocythere ex gr. transoceanica would be more appropriate. Nevertheless, the two main ribs that characterize the central surface ornamentation in $T$. ex. gr. transoceanica and $T$. trindadensis sp. nov. have markedly different orientation. For example, particularly in the first species, the upper rib is born at the wing-like projection extending antero-ventrally and crossing the subcentral tubercle, whereas in the new species the upper rib diverges from the dorsal rib at $1 / 3$ from the posterior cardinal angle and passes above the subcentral few developed swelling. The second lower rib is more weakly defined in $T$. ex gr. transoceanica, shorter and crosses the subcentral tubercle ventral and parallel to the upper rib, whereas in the species described herein the second rib is born at the antero-ventral margin, follows a curved path that runs upward and just in anterior to the subcentral swelling recurves, crossing the swelling, and continues straight, ending approximately at $1 / 3$ before reaching the posterior margin. Tenedocythere trindadensis sp. nov. is also slightly smaller, possesses a different reticulation pattern, has less numerous and pronounced ribs and the posterior margin is less laterally compressed than in $T$. ex gr. transoceanica, which is also more angled sub-ventrally and less concave above. Some variations in adult specimens of the new species have been observed concerning the second central lower rib, which may be short and straight, long and somewhat sinuous or long and straight before reaching the subcentral tubercle.

\section{DISCUSSION AND CONCLUDING REMARKS}

The species richness and the abundance of ostracodes in both study areas are low and no endemic species have been recorded so far. Among the species left in open nomenclature it is possible that some might be endemic. However, additional material is necessary to confirm the identity of these species.

This apparent lack of endemicity is significant because, when compared with other oceanic islands, some of them isolated for hundreds of kilometres (e.g. Cape Verde Archipelago, Clipperton Island, Eastern Island, Galapagos
Islands, Marion/Prince Eduard Islands, Réunion Island), the Trindade Island and Rocas Atoll are components of two chains of seamounts associated with the Trindade-Vitória Alignment (Figure 2) and the Fernando de Noronha Fracture Zone (Figure 3), respectively. About $21 \mathrm{ka} \mathrm{BP}$ the last glacial event (= LGM) reached its maximum leaving the summits of some seamounts in a shallower position or even partially emerged, creating shallow water environments in oceanic regions. After the deglacial, it was only about between 19-7 $\mathrm{ka}$ BP that the sea level rose to the nowadays marks (about $130 \mathrm{~m}$ higher). Therefore, migration routes linking those areas to the Brazilian shelf during sea-level lowstands may explain the relatively cosmopolitan aspect of the faunas.

The present authors interpret the low abundance of ostracodes at Rocas Atoll to be a consequence of the predominantly coarse to very coarse sediments and a narrow shelf around the atoll, which probably do not allow the establishing of a rich and abundant benthic fauna. On the other hand, this hypothesis could be not true for Trindade Island, where medium sand dominates the samples. As discussed above in 'Faunal analysis', marine biodiversity of Trindade is considered one of the poorest among tropical islands in the world, and then the relative low species richness for ostracodes is simply a pattern followed also by other benthic groups previously studied in the area. The explanation for this low diversity, however, could not be fully explained by the available data and are beyond the objectives of the present study.

Furthermore, two species particularly dominate the Trindade samples: Paracytheridea tschoppi Bold, 1946 and Loxoconcha bullata Hartmann, 1956. The first is also very abundant in the Brazilian equatorial shelf and occurs sporadically along the northeastern Brazilian shelf (Purper \& Ornellas, 1987), whereas L. bullata has been recorded in southeastern and southern Brazil where it can withstand some changes in salinity and temperature and dwell not only bottom sediments, but Sargassum mats (see Coimbra \& Bergue, 2003; Coimbra et al., 2007). According to the species recovered in these two study areas, it seems that interchange between the equatorial and northeast Brazilian shelves and the seamounts was probably more effective at Rocas Atoll, which is much closer to the Brazilian coast than Trindade Island.

Pandemic species and those considered to be typical Caribbean inhabitants and some others that are characteristic of the Brazilian shelf are present at the study sites. A few species have experienced long passive spread (coming from the Indian and Pacific oceans) during times of low sea level in the Quaternary. Australimoosela polypleuron and Tenedocythere trindadensis sp. nov. have their centres of abundance at Trindade Island. Australimoosela is a wellknown Pacific ostracode genus whereas A. polypleuron is unique to the Atlantic Ocean. In a study along the Brazilian equatorial shelf, Coimbra at al. (2004) analyzed 339 samples and reported this species only in seven $(\sim 60$ specimens in total), all of them localized to the SW of the mouth of the Amazon River. Thus, the five specimens of $A$. polypleuron recovered from Trindade are not so few since just 11 samples 
were investigated. On the other hand, T. trindadensis sp. nov. possesses a rather high abundance at Trindade contrasting with less than 20 specimens recorded along the entire Brazilian equatorial shelf. This species is also rare at Rocas Atoll. It is quite possible that these species originated on Trindade Island and only recently dispersed to the continental shelf and then to the Rocas Atoll.

It is also important to note that some well-known circumtropical shallow-water ostracodes are absent in both sites, such as Neomonoceratina mediterranea (Ruggieri, 1953), Keijia demissa (Brady, 1868) and Kangarina abyssicola (Mueller, 1894). The first two have an IndoPacific origin and the last is of Tethyan origin, all of them having experienced a long period of evolutionary stasis and geographical dispersal. Despite being pandemic, these three species are normally a minor component in the ostracode faunas where they occur, a phenomenon also present in the Brazilian equatorial shelf (see Coimbra et al., 1999b). It is, therefore, possible that their absence in Trindade and Rocas is not real, but due their small populations and to the relative paucity of sampling. However, further sampling is required to test this hypothesis.

The ostracode faunas of the South Atlantic Trindade Island and Rocas Atoll are markedly less rich than those of the Pacific and Indo-Pacific tropical oceanic islands regardless of the context of sampling. Even when compared with the relatively small and largely isolated Marion/Prince Edward islands $\left(46^{\circ} 54^{\prime} \mathrm{S}, 37^{\circ} 44^{\prime} \mathrm{E}\right)$, in the southern Indian Ocean $\left(\sim 6^{\circ}\right.$ of latitude south of the Sub-Tropical Convergence), the faunas studied herein are much more impoverished. This is also true when one compares the shelf benthic ostracode fauna of the Atlantic Ocean with those of the Indo-Pacific and SW Pacific oceans, since these two last areas have been reported as centres of evolutionary radiation for several marine invertebrate groups including Ostracoda (see Whatley 1987, Coimbra et al. 1999b).

\section{ACKNOWLEDGMENTS}

The authors are indebted to C.P. Machado, I.I. Leipnitz, N.G. Drozinski and V.G. Ghilardi who collected the samples with the support of the Brazilian marine crew. S. McLoughlin is acknowledged for his constructive comments on an early draft; and C.T. Bergue and J. Rodríguez-Lázaro for their critical review of the manuscript, making it publishable. The authors also thank S.M. Petró for his help with the figures and Y. Hornelas for SEM photography. The first author gratefully acknowledges the CNPq (Brazilian National Council for Scientific and Technological Development) for financial support (proc. 300703/2009-0).

\section{REFERENCES}

Allison, E.C. \& Holden, J.C., 1971. Recent ostracodes from Clipperton Island, Eastern Tropical Pacific. Transactions of San Diego Society of Natural History, 16:165-214.

Almeida, F.F.M. 1955. Geologia e Petrologia do Arquipélago de Fernando de Noronha. Rio de Janeiro, Departamento Nacional da Produção Mineral, Divisão de Geologia e Mineralogia, 181 p. (Monografia 13).
Almeida, F.F.M. 2002. Ilha da Trindade: registro de vulcanismo cenozóico no Atlântico Sul. In: C. Schobbenhaus et al. (eds.) Sítios geológicos e paleontológicos do Brasil, Departamento Nacional da Produção Mineral, p. 369-377.

Almeida, F.F.M. 2006. Ilhas oceânicas brasileiras e suas relações com a tectônica atlântica. Terrce Didatica 2:3-18.

Alves, R.J.V. 1998. Ilha da Trindade e Arquipélago Martin Vaz: um ensaio geobotânico. Rio de Janeiro, Serviço de Documentação da Marinha, $143 \mathrm{p}$.

Alves, R.J.V. \& Castro, J.W.A. 2006. Ilhas oceânicas brasileiras: da pesquisa ao manejo. Brasília, IBAMA/Ministério do Meio Ambiente, $299 \mathrm{p}$.

Alves, R.J.V. \& Guimarães, E.F. 1998. Piperaceae da Ilha da Trindade. Brades, 8:97-100.

Antonietto, L.S.; Machado, C.P.; Do Carmo, D.A. \& Rosa, J.W.C. 2012. Recent Ostracoda (Arthropoda, Crustacea) from São Pedro-São Paulo Archipelago, Brazil: a preliminary approach. Zootaxa, 3335:29-53.

Bate, R.H.; Whittaker, J.E. \& Mayes, C.A. 1981. Marine Ostracoda of the Galapagos Islands and Ecuador. Zoological Journal of the Linnean Society, 73:1-79.

Be',A.W.H. \& Hutson, W.H. 1977. Ecology of planktonic foraminifera and biogeographic pattern of life and fossil assemblages in the Indian Ocean. Micropaleontology, 23:369-414.

Breure, A.S. \& Coelho, A.C.S. 1976. Notes on Bulimulidae (Gastropoda, Euthyneura), 3. Bulimulus trindadensis, sp. nov. from Ilha da Trindade, Brasil. Basteria, 40:3-6.

Brito, I.M. 1971. Contribuição ao conhecimento dos equinodermas da Ilha da Trindade, Brasil. Arquivos do Museu Nacional, 54:261-265.

Brouwers, E.M., 1988. Palaeobathymetry on the continental shelf based on examples using ostracods from the Gulf of Alaska. In: P. de Deckker; J.-P. Colin \& J.-P. Peypouquet (eds.) Ostracoda in the Earth Sciences, Elsevier, p. 55-76.

Carroll, M.; Kowalewski, M.; Simões, M.G. \& Goodfriend, G. 2003. Quantitative estimates of time-averaging in terebratulid brachiopod shell accumulations from a modern tropical shelf. Paleobiology, 29:381-402. doi:10.1666/00948373(2003)029<0381:QEOTIT>2.0.CO;2

Carvalho, J.P. 1950. Resultados científicos do cruzeiro do "Baependi" e do "Vega" à Ilha da Trindade: Peixes. Boletim do Instituto Paulista de Oceanografia, 1:97-133.

Coelho, A.C.S. 1974. Contribuição ao conhecimento dos moluscos bivalves marinhos da Ilha da Trindade, Brasil. Museu Nacional,Tese de Livre Docência, 65 p.

Coimbra, J.C. \& Bergue, C.T. 2003. A new recent marine Ostracoda species (Hemicytheridae) from Brazil. Iheringia, Série Zoologia, 93:243-247. doi:10.1590/S0073-47212003000300003

Coimbra, J.C.; Carreño, A.L. \& Michelli, M. J. 1999a. Taxonomía y zoogeografía de la Família Cytheruridae (Ostracoda) de la plataforma continental ecuatorial de Brasil. Iheringia, Série Zoología, 87:117-142.

Coimbra, J.C.; Carreño, A.L.; Geraque, E.A. \& Eichler, B.B. 2007. Ostracodes (Crustacea) from Cananéia-Iguape estuarine/ lagoon system and geographical distribution of the mixohaline assemblages in southern and southeastern Brazil. Iheringia, Série Zoología, 97:273-279. doi:10.1590/S0073-47212007000300010

Coimbra, J.C.; Costa, K.B. \& Fauth, G. 2006. Palaeoenvironmental significance of allochthonous vs. autochthonous late Quaternary ostracodes from Imaruí Lagoon and D’Una River, Southern Brazil. Revista Brasileira de Paleontologia, 9:295-302.

Coimbra, J.C.; Ghilardi, V.G.; Casetta, G.M. \& Bergue, C.T., 2009. Ostracoda. In: L.V. Mohr; J.W.A. Castro; P.M.S. Costa \& R.J.V. Alves (eds.) Ilhas oceânicas brasileiras: da pesquisa ao manejo, IBAMA/ Ministério do Meio Ambiente, v. 2, p. 125-141. 
Coimbra, J.C.; Pinto, I.D.; Würding, N. \& Carmo, D.A. 1999b. Zoogeography of Holocene Podocopina (Ostracoda) from the Brazilian continental shelf. Marine Micropaleontology, 37:365379. doi:10.1016/S0377-8398(99)00025-0

Coimbra, J.C.; Ramos, M.I.F. \& Sanguinetti, Y.T. 1992. SubRecent ostracodes of the Tamandaré Bay, northeastern Brazil: a preliminary report on biofacies. Pesquisas, 19:94-105.

Coimbra, J.C.; Ramos, M.I.F.; Whatley, R.C. \& Bergue, C.T. 2004. The taxonomy and zoogeography of the family Trachyleberididae (Crustacea: Ostracoda) from the Equatorial continental shelf of Brazil. Journal of Micropalaeontology, 23:107-118. doi:10.1144/ jm.23.2.107

Cronin, T. 1988. Geographical isolation in marine species: evolution and speciation in Ostracoda, I. In: T. Hanai; N. Ikeya \& K. Ishizaki (eds.) Evolutionary Biology of Ostracoda, Elsevier, p. 871-889.

Dingle, R.V. 2002. Insular endemism in Recent southern ocean benthic Ostracoda from Marion island: paleozoogeographical and evolutionary implications. Revista Española de Micropaleontología, 34:215-233.

Dingle, R.V. 2003. Recent subantartic benthic Ostracoda faunas from the Marion and Prince Edward Islands Archipelago, southern ocean. Revista Española de Micropaleontologia, 35:119-155.

Fauth, G. \& Coimbra, J.C. 1998. Zoogeography of the ostracode genera Auradilus and Radimella (Ostracoda) along the Brazilian continental shelf. Neues Jahrbuch für Geologie und Paläontologie, Monatshefte, 8:463-474.

Ferrari, A.L. \& Ricomini, C. 1999. Campo de esforços pliopleistocênico na Ilha da Trindade (Oceano Atlântico Sul, Brasil) e sua relação com a tectônica regional. Revista Brasileira de Geociências, 29:195-201.

Floeter, S.R.; Rocha, L.A.; Robertson, D.R.; Joyeux J.C.; Smith-Vaniz, W.F.; Wirtz, P.; Edwards, A.J.; Barreiros, J.P.; Ferreira, C.E.L.; Gasparini, J.L.; Brito, A.; Falcón, J.M.; Bowen, B.W. \& Bernardi, G. 2008. Atlantic reef fish biogeography and evolution. Journal of Biogeography, 35:22-47. doi:10.1111/j.1365-2699.2007.01790.x

Hartmann, G. 1978. Die ostracoden der Ordnung Podocopida G.W. Müller, der tropischen-subtropischen ostküste Australiens (zwischen Eden in Süden und Heron Island im Norden). Mitteeilungen Hamburg Zoologischen Instituten, 78:97-149.

Hartmann, G. 1984. Zur Kenntnis der Ostracoden der polynesischen Inseln Huahiné (Gesellschaftsinseln) und Rangiroa (TuamotuInseln). Mitteeilungen Hamburg Zoologischen Instituten, 81:117-169.

Jellinek, T.1995. The Plio-/Pleistocene genus Mutilus Neviani 1955 (Ostracoda) and some of its so-called Recent descendants. Senkenbergiana lethaea, 75:163-191.

Joly, A.B. 1950. Resultados científicos do cruzeiro do "Baependi" e do "Vega" à Ilha Trindade: nota preliminar sobre algumas algas. Boletim do Instituto Paulista de Oceanografia, 1:73-75.

Keyser, D. \& Schöning, C. 2000. Holocene Ostracoda (Crustacea) from Bermuda. Senckenbergiana Lethaea, 80:567-591. doi:10.1007/BF03043366

Kikuchi R.K.P. 2002. Atol das Rocas, litoral do nordeste do Brasil. In: C. Schobbenhaus et al. (eds.) Sítios geológicos e paleontológicos do Brasil, Departamento Nacional da Produção Mineral, p. 379-390.

Kowalewski, M.; Ávila-Serrano, G.E.; Flessa, K.W. \& Goodfriend, G.A. 2000. A dead delta's former productivity: two trillion shells at the mouth of the Colorado River. Geology, 28:1059-1062. doi: 10.1130/0091-7613(2000)28<1059:DDFPTT>2.0.CO;2

Kowalewski, M.; Flessa, K.W. \& Aggen, J.A. 1994. Taphofacies analysis of Recent shelly cheniers (beach ridges), northeastern Baja California, Mexico. Facies, 31:209-242.

Kowalewski, M.; Goodfriend, G.A. \& Flessa, K.W.1998. The highresolution estimates of temporal mixing in shell beds: the evils and virtues of time-averaging. Paleobiology, 24:287-304.
Kowalewski, M.; Simões, M.G.; Carroll, M. \& Rodland. D.L. 2002. Abundant articulated brachiopods on a tropical, upwelling-influenced shelf (Southeast Brazilian Bight, South Atlantic). Palaios, 17:277-286. doi:10.1669/0883-1351(2002) 017<0277:ABOATU>2.0.CO;2

Krause Jr., R.A.; Barbour, S.L.; Kowalewski, M.; Kaufman, D.S.; Romanek, C.S.; Simões, M.G. \& Wehmiller, J.F. 2010. Quantitative comparisons and models of time-averaging in bivalve and brachiopod shell accumulations. Paleobiology, 36:428-452. doi:10.1666/08072.1

Lanzieri, P.D. 1966. A família Succineidae (Gastropoda: Pulmonata) da Ilha da Trindade, costa do Brasil. Papéis Avusos de Zoologia de São Paulo, 19:170-188.

Larwood, J.G. \& Whatley, R.C. 1993. Tertiary to Recent evolution of ostracodes in isolation on seamounts. In: K.G. Mckenzie \& P. Jones (eds.) Ostracoda in Earth and Life Sciences, Elsevier, p. 531-549.

Liebau, A. 2005. A revised classification of the higher taxa of the Ostracoda (Crustacea). Hydrobiologia, 538:115-137.

Machado, C.P.; Coimbra, J.C. \& Carreño, A.L. 2005. The ecological and zoogeographical significance of the sub-Recent Ostracoda off Cabo Frio, Rio de Janeiro State, Brazil. Marine Micropaleontology, 55:235-253. doi: 10.1016/j.marmicro.2005.03.002

Machado, A.J. \& Souza, F.B.C. 1994. Principais espécies de foraminíferos e briozoários do Atol das Rocas. Revista Brasileira de Geociências, 24:247-261.

Maddocks, R.F. 2007. Podocopid and platycopid Ostracoda of New Caledonia. In: C.E. Payri \& B. Richard de Forges (eds.) Compedium of marine species of New Caledonia, $2^{\mathrm{a}}$ ed., Institut de Recheche pour le Développement de Nouméa/New Caledonia, 269-273.

Martin, R.E. 1999. Taphonomy: a process approach. Cambridge, Cambridge University Press, 526 p.

Moraes, F.; Ventura, M.; Klautau, M.; Hajdu, E. \& Muricy, G. 2006. Biodiversidade de esponjas das ilhas oceânicas brasileiras. In: R.J.V. Alves \& J.W.A. Castro (eds.) Ilhas oceânicas brasileiras: da pesquisa ao manejo, IBAMA/Ministério do Meio Ambiente, p. 148-178.

Mostafawi, N.; Colin, J.-P. \& Babinot, J.-F. 2005. An account of the taxonomy of ostracodes from recent reefal flat deposits in Bali, Indonesia. Revue de Micropaléontologie,48:123-140.

Nassar, C.A.G. 1994. An assessment to the benthic marine algae at Trindade Island, Espirito Santo, Brazil. Revista Brasileira de Biologia, 54:623-629.

Paulay, G.; Kropp, R.; Ng, P.K.L. \& Endredge, L.G. 2003. The crustaceans and pycnogonids of the Mariana Islands. Micronesica, 35/36:456-513.

Pedrini, A.G. 1989. A survey of the marine algae of Trindade Island, Brazil. Botanica Marina, 32:97-99.

Pereira-Filho, G.H.; Amado-Filho, G.M.; Guimarães, S.M.P.B.; Moura, R.L.; Sumida, P.Y.G.; Abrantes, D.P.; Bahia, R.G.; Güth, A.Z.; Jorge, R.R. \& Francini Filho, R.B. 2011. Reef fish and benthic assemblages of the Trindade and Martin Vaz Island group, southwestern Atlantic. Brazilian Journal of Oceanography, 59:201-212.

Peterson, R.G. \& Stramma, L. 1991. Upper-level circulation in the South Atlantic Ocean. Progress in Oceanography, 26:1-73.

Pinheiro, H.T.; Camilato, V.; Gasparini, J.L. \& Joyeux, J. 2009. New records of fishes for Trindade-MartinVaz oceanic insular complex, Brazil. Zootaxa, 2298:45-54.

Pinto, S.D. 1957. Um novo Clinidae na Ilha da Trindade, Brasil (Actinopterygii, Perciformes). Boletim do Museu Nacional, nova série, Zoologia, 163:1-15.

Pokorný, V. 1970. The genus Radimella Pokorný, 1969 (Ostracoda, Crustacea) in the Galapagos Islands. Acta Universitatis Carolinae, Geologica, 4:293-334.

Pokorný, V. 1972. The genus Caudites Coryell \& Fields, 1937 (Ostracoda, Crustacea) in the Galapagos Islands. Acta Universitatis Carolinae, Geologica, 4:267-302. 
Purper, I. \& Ornellas, L.P. 1987. Paracytheridea tschopii van den Bold, 1946 and its allied species, Paracytheridea batei Purper et Ornellas, sp. nov. in the Brazilian continental shelf. In: CONGRESSO BRASILEIRO DE PALEONTOLOGIA, 10, 1987. Anais, Rio de Janeiro, SBP, v. 1, p. 747-759.

Ramos, M.I.F. 1996. Taxonomy and zoogeography of the ostracode genera Nanocoquimba and Cornucoquimba Ohmert, 1968 from Recent sediments on the Brazilian continental shelf. Revista Española de Micropaleontología, 28:105-128.

Rodrigues, M.A. 1971. Foraminíferos recentes da Ilha da Trindade. Anais da Academia Brasileira de Ciências, 43:643-654.

Rossi, A.R.; Leipnitz, I.I. \& Leipnitz, B. 1996. Foraminíferos holocênicos do Atol das Rocas. Acta Geologica Leopoldensia, 44:77-91.

Tavares, M. 1999. The cruise of the Marion Dufresne of the Brazilian coast: account of the scientific results and list of stations. Zoosystema, 21:597-605.

Teeter, J.W. 1975. Distribution of Holocene marine Ostracoda from Belize. In: K.F. Wantland \& W.C. Pusey III (eds.) Belize shelfcarbonate sediments, clastic sediments, and ecology, AAPG, p. 400-499.

Thomaz Filho, A. \& Rodrigues, A.L. 1999. O alinhamento de rochas alcalinas Poços de Caldas-Cabo Frio (RJ) e sua continuidade na cadeia Vitória-Trindade. Revista Brasileira de Geociências, 29:189-194.

Tinoco, I.M. 1965. Foraminíferos do Atol das Rocas. Trabalhos do Instituto Oceanográfico da Universidade de Pernambuco, 7/8:91-114.

Tinoco, I.M. 1972. Foraminíferos dos bancos da costa nordestina, Atol das Rocas e Arquipélago de Fernando Noronha. Trabalhos do Instituto Oceanográfico da Universidade de Pernambuco, 13:49-60.

Titterton, R. \& Whatley, R.C. 1988a. Recent Bairdiinae (Crustacea, Ostracoda) from the Solomon Islands. Journal of Micropalaeontology, 7:111-142.

Titterton, R. \& Whatley, R.C. 1988b. The provincial distribution of shallow water Indo-Pacific marine Ostracoda: origins, antiquity, dispersal routes and mechanisms. In: T. Hannai; N. Ikeya \& K. Ishizaki (eds.) Evolutionary biology of Ostracoda, its fundamentals and applications, Elsevier, p. 759-786.

Titterton, R. \& Whatley, R.C. 2005. Recent marine Ostracoda from the Solomon Islands, Part 2. Cytheracea, Xestoleberididae. Revista Española de Micropaleontología, 37:291-313.

Titterton, R. \& Whatley, R.C. 2006a. Recent marine Ostracoda from the Solomon Islands, Part 1. Cypridoidea, Platycopina and Cladocopina. Journal of Micropalaeontology, 25:73-94.

Titterton, R. \& Whatley, R.C. 2006b. Recent marine Ostracoda from the Solomon Islands, Part 3. Cytheroidea: Bythocytheridae, Cytherideidae, Krithidae, Neocytherideidae, Cytheruridae. Revista Española de Micropaleontología, 38:169-189.

Titterton, R. \& Whatley, R.C. 2007. Recent marine Ostracoda from the Solomon Islands, Part 5. Cytheroidea, Leptocytheridae. Revista Española de Micropaleontología, 39:45-62.

Titterton, R. \& Whatley, R.C. 2008. Recent marine Ostracoda from the Solomon Islands, Part 4. Cytheroidea: Hemicytheridae, Thaerocytheridae. Journal of Micropalaeontology, 27:13-33.

Titterton, R. \& Whatley, R.C. 2009a. Recent marine Ostracoda from the Solomon Islands, Part 6. Chyteroidea: Paradoxostomatidae, Pectocytheridae, Trachyleberidae. Revista Española de Micropaleontología, 41:35-74.

Titterton, R. \& Whatley, R.C. 2009b. Recent marine Ostracoda from the Solomon Islands, Part 7. Cytheroidea: Loxoconchidae. Revista Española de Micropaleontología, 41:295-314.

Titterton, R. \& Whatley, R.C. 2010. A short nomenclature note: new names for the Recent ostracod species Paradoxostoma dorsostriata Titterton \& Whatley, 2009a and Loxoconcha athersuchi Titterton \& Whatley, 2009b. Revista Española de Micropaleontología, 42:275.

Van Morkhoven, F.P.C. M. 1972. Bathymetry of Recent Marine Ostracoda in the Northwest Gulf of Mexico. Transactions Gulf Coast Association of Geological Societies, 22:241-252.

Vannucci, M. 1950. Resultados científicos do cruzeiro do "Baependi" e do "Vega" à Ilha Trindade: Hydrozoa. Boletim do Instituto Paulista de Oceanografia, 1:81-86.

Villaça, R.; Pedrini, A.G.; Pereira, S.M.B. \& Figueiredo, M.A.O. 2006. Flora marinha bentônica das ilhas oceânicas brasileiras. In: R.J.V. Alves \& J.W.A. Castro (eds.) Ilhas oceânicas brasileiras: da pesquisa ao manejo, IBAMA/Ministério do Meio Ambiente, p. 107-146.

Weissleader, L.S.; Gilinsky, N.L.; Ross, R.M. \& Cronin, T.M., 1989. Biogeography of marine podocopid ostracodes in Micronesia. Journal of Biogeography, 16:103-114.

Whatley, R.C. 1983. Some simple procedures for enhancing the use of Ostracoda in palaeoenvironmental analysis. Norwegian Petroleum Directorate, Bulletin, 2:129-146.

Whatley, R.C. 1987. The southern end of Tethys: an important locus for the origin and evolutionary of both deep and shallow water Ostracoda. In: INTERNATIONAL SYMPOSIUM ON SHALLOW TETHYS, 2, 1987. Proceedings, Rotterdam, p. 461-474.

Whatley, R.C. 2000. The zoogeographical significance of the marine Ostracoda of Easter Island. Revista Española de Micropaleontología, 32:147-156.

Whatley, R.C. \& Boomer, I. 1995. Autochthonous and allochthonous Quaternary Ostracoda from ODP Site 893, Santa Barbara Basin. In: J.P. Kennett; J.G. Baldauf \& M. Lyle (eds.) Proceedings of the Ocean Drilling Program, Houston, p. 251-255 (Scientific Results 146).

Whatley, R.C. \& Keeler, N. 1989. Ostracodes actuels de l'Île de la Réunion (Sud-Ouest de l'Océan Indien). Revue de Micropaléontologie, 32:63-84.

Whatley, R.C. \& Jones, R. 1999. The marine podocopid Ostracod of Easter Island a paradox in zoogeography and evolution. Marine Micropaleontology, 37:327-343.

Whatley, R.C.; Jones, R. \& Roberts, R. 2004. The marine Ostracoda of Pitcairn, Oeno and Henderson islands, southern Pacific. Revista Española de Micropaleontología, 36:493-528.

Whatley, R.C. \& Roberts, R. 1995. The Pitcairn islands: biogeography, ecology and prehistory. Biological Journal of the Linnean Society, 56:359-364.

Whatley, R.C. \& Titterton, R. 1981. Some new Recent podocopid Ostracoda from the Solomon Islands south-west Pacific. Revista Española de Micropaleontología, 13:157-170.

Whatley, R.C.; Jones, R., \& Wouters, K. 2000. The marine Ostracoda of Easter Island. Revista Española de Micropaleontología, 32:79-106.

Whittaker, R.J. \& Fernandez-Palacios, J.M. 2007. Island biogeography: ecology, evolution, and conservation. $2^{\mathrm{a}} \mathrm{ed}$. Oxford, Oxford University Press, 403 p.

Witte, L. \& Van Harten, D. 1991. Polymorphism, biogeography and systematics of Kotoracythere inconspicua (Brady, 1880) (Ostracoda: Pectocytheridae). Journal of Biogeography, 18:427-436.

Wouters, K. 2003. Taxonomy and zoogeography of intertidal Ostracoda (Crustacea) from the Cape Verde Islands (Atlantic Ocean). Bulletin Koninklijk Belgisch Instituut voor Natuurwetenschappen, Biologie, 71:137-159.

Yoneshigue-Valentin, Y.; Gestinari, L.M.S. \& Fernandes, D.R.P. 2005. Macroalgas. In: Biodiversidade bentônica da região central da Zona Econômica Exclusiva Brasileira, Rio de Janeiro, Museu Nacional, p. 67-105 (Série Livros 18).

Received in January, 2012; accepted in July, 2012. 
Appendix 1. Ostracode species examined in this study.

Family Bairdiidae Sars, 1888

Genus Glyptobairdia Stephenson, 1946

Glyptobairdia coronata (Brady, 1870)

Genus Neonesidea Maddocks, 1969

Neonesidea $\mathrm{sp} .1$

Neonesidea? spp.

Genus Paranesidea Maddocks, 1969

Paranesidea parabipustulosa Coimbra \& Carreño, 2002

Genus Triebelina Bold, 1946

Triebelina sertata Triebel, 1948

Bairdiidae indet. 1

Bairdiidae indet. 2

Family Candonidae Kaufmann, 1900

Genus Paracypris Sars, 1866

Paracypris sp.

Family Cytherellidae Sars, 1866

Genus Keijcyoidea Malz, 1981

Keijcyoidea amazonica Bergue \& Coimbra, 2002

Keijcyoidea sp.

Family Cytheruridae Müller, 1894

Genus Cytherura Sars, 1866

Cytherura sp.

Genus Hemicytherura Elofson, 1941

Hemicytherura bradyi (Puri, 1960) emend. Coimbra, Carreño \& Michelli, 1999

Genus Paracytheridea Müller, 1894

Paracytheridea batei Purper \& Ornellas, 1987

Paracytheridea tschoppi Bold, 1946

Family Hemicytheridae Puri, 1953

Genus Auradilus Jellinek, 1995

Auradilus costatus (Hu, 1979)

Genus Caudites Coryell \& Fields, 1937

Caudites exmouthensis Hartmann, 1978

Caudites obliquecostatus Bold, 1963

Caudites seminudus Whatley \& Keeler, 1989

Caudites sp.

Genus Nanocoquimba Ohmert, 1968

Nanocoquimba labyrinthica Ramos, 1996

Genus Orionina Puri, 1953

Orionina bradyi Bold, 1963

Genus Radimella Pokorný, 1969

Radimella confragosa (Edwards, 1944)

Genus Tenedocythere Sissing, 1972

Tenedocythere ex gr. transoceanica (Teeter, 1975)

Tenedocythere trindadensis sp. nov.

Family Loxoconchidae Sars, 1925

Genus Loxoconcha Sars, 1866

Loxoconcha bullata Hartamnn, 1956

Loxoconcha sp.

Loxocorniculum tricornatum Krutak, 1971

Family Macrocyprididae Müller, 1912

Genus Macrocyprina Triebel, 1960

Macrocyprina sp.

Family Paradoxostomatidae Brady \& Norman, 1889

Genus Pellucistoma Coryell \& Fileds, 1937

Pellucistoma sp.

Family Pectocytheridae Hanai, 1957

Genus Kotoracythere Ishizaki, 1966

Kotoracythere insconspicua (Brady, 1880)

Family Trachyleberididae Sylvester-Bradley, 1948

Genus Australimoosella Hartmann, 1978

Australimoosella polypleuron Coimbra, Ramos, Whatley \& Bergue, 2004

Genus Puriana Coryell \& Fields, 1953

Puriana variabilis Chukewiski \& Purper, 1985

Puriana convoluta Teeter, 1975

Family Xestoleberididae Sars, 1928

Genus Xestoleberis Sars, 1866

Xestoleberis sp. 1

Xestoleberis sp. 2

Xestoleberis sp. 3

Family Paradoxostomatidae Brady \& Norman, 1889

Genus Sclerochilus Sars, 1866

Sclerochilus sp. 